for extinction, and R. Parthasarathy (India) described some new measurements of intensities reflected by perfect and imperfect crystals. Prof. M. Renninger (West Germany) described a technique whereby lattice deformations of the order of less than a tenth of a second of arc can be made visible by a double spectrometer device, and Prof. N. Kato (Japan) diseussed the application of the dynamical theory of wave diffraction to the study of slightly distorted crystals. Disorder phenomena were discussed by Prof. H. Jagodzinsky (West Germany), who outlined their general nature and pointed out that a mathematical treatment of disorder in two or three dimensions is difficult to work out. Prof. I. Waller (Sweden) spoke on the influence of crystal vibrations, as affected by impurities and anharmonicities, on neutron scattering and on the Mossbauer effect. He was followed by Prof. Ajit Ram Verma (India), who presented the results of his investigations on disorder in silicon carbide, and by Prof. A. J. C. Wilson (United Kingdom), who dealt with the measurement of line-broadening in X-ray powder diffractometry.

Electron and neutron diffraction were discussed by Prof. S. Miyake (Japan) and his colleagues, who described an electron diffraction investigation of phthalocyanine and its metal derivatives; by Dr. J. Shankar (India), who reviewed the use of neutron diffraction in the study of hydrogen bonding; and by Dr. P. K. Iyengar (India), who described the powder and single-crystal diffractometers constructed at Trombay, India, for use with neutrons. Instruments for crystallographic studies were also described by Dr. W. A. Wooster (Ưnited Kingdom), who has developed an automatic four-circle counter diffractometer; and by A. K. Singh and Prof. S. Ramaseshan (India), who have made an integrating Weissenberg camera for use at low and high temperatures.

In the last session, Prof. J. Laval (France) gave the theory of the elastic properties of metallic crystals having cubic symmetry; Prof. R. S. Krishnan (India) discussed the infra-red and Raman spectra of glycine and related compounds in the orystalline state; Dr. S. S. Mitra (United States) gave an account of infra-red absorption in ionic erystals; and Prof. Zheludev (U.S.S.R.) spoke on the so-called anti-tensors and their symmetry, which are important in connexion with the colour groups developed by Russian crystallographs.

The symposium was attended by about 40 overseas and 150 Indian delegates, who enjoyed the organization and stimulating programme arranged by Prof. Ramachandran and his colleagues. Its success was much to the credit of one of the regrettably fow university departments in the Commonwealth that are devoted to the teaching and practice of biophysics.

D. C. Phillips

\title{
COMMUNICATION SATELLITE RESEARCH IN BRITAIN
}

$I^{\mathrm{N}}$ opening a debate in the House of Commons on March 25 on Post Office capital investment and tariff increases, the Postmaster-General, Mr. R. Bevins, referred briefly to satellite communications and said that, so far as could be judged, this would be the cheapest method of providing the increased capacity needed to handle the very rapid expansion in international telephoning; submarine cables and satellites would probably be supplementary systems for many years to come. Since about 80 per cent of inter-continental traffic was across the Atlantic Ocean between North America and Europe, any satellite system that was to pay must draw to some extent on trans-Atlantic traffic, and that was why the Post Office was putting much work at the political, administrative and scientific levels into the associated problems. At present, between $£ 1$ and $£ 2$ million was allocated for Post Office research as such.

The whole question of telecommunications space satellites was debated on March 29, when a motion of $\mathrm{Mr}$. Farey-Jones-asking the Government to announce plans for the provision of a British and Commonwealth telecommunications satellite and to treat the matter as one of great urgency to maintain British leadorship in communications, to prevent the dissipation of existing design staffs, and to restore confidence in the future of British scientists-was adopted. In this debate the Assistant Postmaster-General, Mr. R. Mawby, repeating Mr. Bevin's remark about the need for such a system to carry traffic from the United States, said that the British share of world inter-continental traffic was 10 per cent, and the whole traffic between Commonwealth countries only 20 per cent. Revenue from traffic originating and terminating in the United States was expected to be $75-80$ per cent of the total by 1975 . Of the present 2.4 million intercontinental telephone ealls a year, only 600,000 did not cross the Atlantic; by 1970 the latter figure was expected to inerease to about 3 million and to 9 million by 1980 , but this would still represent only 30 per cent of the total inter-continental traffic. It was unlikely that the revenue available to support a global system giving world-wide coverage would exeeed $\mathfrak{£} 60$ million a year by 1970.
Britain's own investigations were directed to a system utilizing twelve stations keeping satellites in equatorial orbit, the capital cost of which might be $£ 160-190$ million and the annual cost £32-37 million. The experimental ground station built at Goonhilly Down in Cornwall had already co-operated with brilliant success in the transAtlantic tests with the American experimental telecommunications satellites Telstar and Relay and was believed to be much nearer the design of the ultimate operating station than any other in the world. Its equipment was now being improved and extended so that it would be ready as an operational station when the first system of regular commercial satellites was put into orbit. Britain was also putting in hand a design study for the communications part of the equipment which goes into a satellite and was participating in the necessary complicated pattern of international discussions. A series of exploratory discussions of the broader aspects of the question had opened with the Commonwealth Conference on Satellite Communications in London last spring, followed by preliminary discussions with the United States and Canada in Washington last October, and with European countries at Cologne in December under the ægis of the Conference of European Postal and Telocommunications Administration. An ad hoc committeo set up by this Conference to study the wider aspects of the problem had already met in Paris, was meeting in London in June and would present a considered view to the next plenary meeting in September.

In replying on the debate, the Minister of Aviation, Mr. J. Amery, after explaining that the Ministry of Aviation would be responsible for developing and procuring launchers and satellites that other Departments might need, added that the decisions taken or about to be taken on space communications would have very farreaching implications for Britain's general position as an aero-space power. The European Launcher Development Organization launcher was planned to put a test pay-load into orbit by 1966-67 and should provide the launching capability for an operational satellite system in 1968-69. Britain was about to let contracts with industry for the design and construction of Ariel III, which would be the 
first all-British satellite; Britain was co-operating with several European countries in a scientific space research programme through the European Space Research Organization. The Royal Aircraft Establishment at Farnborough and the Signals Research Development Estab. lishment at Christchurch, which were responsible for the general guidance of the study of the design of a communications satellite, had for some time been bouncing signals off the Moon to each other. He proposes that there should be no restriction on the dissemination within British industry of the information derived from the investigations. Two types of satellite communications system were at present under consideration. The first was the so-called medium orbit of about 7,500 nautical miles, which would call for a dozen or so satellites; the second was the so-called stationary or synchronous orbit requiring a much smaller number of satellites at a height of about 20,000 nautical miles, in which each satellite would remain above the same point on Earth. The effect of the explosion of the American so-called 'rainbow bomb', which might have a damaging effect on the solar cells and other satellite components for at least ten years, was being investigated before decision was made between the two systems. The debate also drew the suggestion that these developments should be made the responsibility of a single Ministry of Science and Technology and welcome for the idea that computing should be a main study at the new University of Essex.

\section{THE NETHERLANDS REACTOR CENTRE}

$\mathrm{F}^{\mathrm{o}}$ OR the second time-the first was in June 1961Atomenergie in haar Toepassingen (Atomic Energy and its Applications), the scientific and technical periodical published under the auspices of the Netherlands Reactor Centre (Reactor Centrum Nederland) has printed a special issue (4, No. 11; November 1962) in English. It contains seventeen articles dealing with the organization, buildings, reactors and research activities of the Reactor Centre. The Centre is situated at Petten on the North Sea coast, about $35 \mathrm{~km}$ north of the Amsterdam shipping canal. The reactors now operational are the lowflux reactor $(L F R)$ of $10 \mathrm{~kW}$ maximum power and $10^{11}$ neutrons $\mathrm{cm}^{-2} \mathrm{sec}^{-1}$ peak thermal flux, and the high-flux reactor $(H F R)$ of $20 \mathrm{MW}$ maximum power and $2 \times 10^{14}$ neutrons $\mathrm{cm}^{-2} \mathrm{sec}^{-1}$ peak thermal flux. A critical experiment reactor (Krito) of some watts maximum power is estimated to become critical in the early part of 1963 . Since 1955, when the Reactor Centrum Nederland was established, the number of staff has increased steadily to 536 at June 1, 1962. 106 of these are graduates, and 351 scientific and technical personnel, with 93 administrative employees.

Separate articles deal with the descriptions of the construction, instrumentation and materials testing of the $H F R$ reactor. The $L F R$, which was constructed by the Hawker Siddeley Nuclear Power Co., Ltd., and which first became critical during September 1960, is described by J. Coehoorn and J. H. B. Madsen. A brief account of the Netherlands development programme for a marine reactor is given by Prof. M. Bogaardt. The main interest of Reactor Centrum Nederland is at present in lightwater-moderated reactors, and both $H F R$ and $L F R$ are of this type. The contract with Euratom for the marine reactor design is also for a light water reactor but of the pressurized type. It is in connexion with this contract that the critical facility (Krito) is being constructed at Petten in the newly built Fermi building, which also houses the LFR reactor. The facility consists of an aluminium tank $(2.5 \mathrm{~m}$ diameter, $4.25 \mathrm{~m}$ height) in which the experimental core can be built up, together with pumps, piping, dump tank and control drive mechanisms, situated within a concrete enclosure $7.5 \mathrm{~m}$ wide, $11 \mathrm{~m}$ long and $12.5 \mathrm{~m}$ high with a wall thickness of $1 \mathrm{~m}$. The first loading will consist of $\mathrm{UO}_{2}$ pellets of $3 \cdot 1$ per cent and 3.8 per cent enrichment canned in aluminium tubes. The full core will contain about 40 boxes of 120 tubes to each box.

One of the joint projects of research being carried out by Norwegian "Institutt for Atomenergi" and Reactor Centrum Nederland is an investigation of plutonium ceramics, and at present work on plutoniumcontaining fuel is concentrated on the development of plutonium-uranium oxide fuels. Transplutonium research is discussed by Dr. W. Kraak and Dr. B. Verkerk, and activation analysis by Dr. H. A. Das.

\section{S. WEINTROUB}

\section{HYGIENE IN MILK PRODUCTION, PROCESSING AND DISTRIBUTION}

\begin{abstract}
IN helping to meet the nutritional needs of an everexpanding world population, milk has a most important part to play, but if milk is to be used efficiently and if waste of such a precious commodity is to be avoided, it must be produced, processed and distributed under the most hygienic conditions that science and good management can achieve. It is a matter for congratulation, therefore, that the World Health Organization, the Food and Agriculture Organization and the United Nations International Children's Emergency Fund have sponsored the production of a comprehensive and authoritativo monograph* dealing not only with conditions in areas where dairying is well established but also with the entirely different picture that exists in the less-developed parts of the world where the climate is so often warmer

* World iiealth Organization. Monograph Series, No. 48: Milk Hygiene. et al. Pp. 782. (Geneva: World Health Organization; London: H.M.S.O., et al. Pp. 782 . (Geneva: World Health
1962.) 38 Sw. franes; 60s.; 12 dollars.
\end{abstract}

and where the need for particularly stringent hygienic measures is especially great.

Thirty-seven experts from all parts of the world, most of them well known internationally throughout the dairy industry, have contributed by writing the 35 chapters and one of the three annexes of which the book con. sists.

The first chapter deals in a most comprehensive way with diseases that can be transmitted through milk, and includes sections on milk allergy, the possible prosence of antibiotics, insecticides, preservatives and other chemicals in milk and other causes of unwholesome milk. Having established the problem involved and the risks that can nowadays be so readily avoided by sound hygiene, the book then provides a section on milk hygiene on the farm. This includes well-illustrated chapters on buildings and installations on dairy farms in both temperate and tropical climates. Then follow chapters on the 